\title{
Ocena możliwości symulacji przepływu płynów złożowych przez „sztuczne” warstwy/złoża z kulek szklanych
}

\begin{abstract}
W artykule przedstawiono ocenę możliwości wykorzystania sztucznych ośrodków porowatych zbudowanych z kulek szklanych o znanej granulacji w celu symulacji przepływu płynów złożowych i zabiegów wspomagania/intensyfikacji wydobycia węglowodorów. Wykonanych zostało 8 modeli złóż o zróżnicowanej budowie i układzie warstw, które scharakteryzowano pod względem podstawowych parametrów petrofizycznych i filtracyjnych. Przeprowadzono wizualizację symulacji procesu nawadniania dwóch modeli heterogenicznych: I - dwie warstwy równoległe o różnej frakcji budujących je kulek szklanych, II - analogiczny model z modyfikacją (redukcją) przepuszczalności określonego fragmentu warstwy spągowej. W prosty sposób zestawiono i porównano poziom nasyceń ropy naftowej po zabiegu nawadniania, weryfikując tym samym poprawność zaprojektowanego eksperymentu symulacji przepływu płynów przez sztuczne warstwy/złoża z kulek szklanych.
\end{abstract}

Słowa kluczowe: przepływ płynów złożowych, sztuczne złoża z kulek szklanych, nawadnianie, współczynnik sczerpania.

\section{Evaluation of potential fluids flow simulation through glass beads pack}

The paper presents an evaluation of potential possibilities of using glass beads pack for reservoir fluids flow and IOR/ EOR treatment simulation. Eight models with various structures and layers layout, and which were characterized in terms of their basic petrophysical and filtration properties were built. For two heterogeneous models waterflooding treatment simulation was carried out: I - two parallel layers with different fraction of glass, II - analogical model with reduction of permeability in base layer. For verification of correctness of designed simulations, the level of oil saturation after waterflooding was compared.

Key words: reservoir fluids flow, glass beads pack, waterflooding, recovery factor.

\section{Wstęp}

Stale wzrastające światowe zapotrzebowanie na źródła energii zbiega się ze spadkiem liczby łatwych w eksploatacji konwencjonalnych złóż węglowodorów [11]. Ze względu na nierównomierne w stosunku do głównych obszarów konsumpcji globalne rozmieszczenie zasobów ropy naftowej, gazu ziemnego oraz innych surowców energetycznych - coraz większym zainteresowaniem cieszą się trudniejsze i kosztowniejsze do zagospodarowania zasoby niekonwencjonalne, np. formacje łupkowe czy piaski bitumiczne [10, 12]. Potencjał, który niosą ze sobą tego typu złoża, jest ogromny, lecz wymaga opracowania i ciągłego doskonalenia technik wydobycia.

Panujące trendy nie powinny wpływać na marginalizację dotychczas odkrytych zasobów. Poniesione koszty prac poszukiwawczych i eksploatacyjnych zobowiązują do podejmowania działań mających na celu zwiększenie stopnia sczer- pania „starych” złóż ropy naftowej, których zasoby są nadal bardzo duże. Nie można tego osiągnąć bez wprowadzania odpowiednich metod wspomagania wydobycia (rysunek 1). Jak wynika z obecnych doświadczeń, prawidłowo przeprowadzone zabiegi intensyfikacji mogą zwiększyć produkcję odwiertu wydobywczego o ponad 100\%. Zrozumienie mechanizmów wypierania płynów złożowych charakteryzujących się zmiennymi właściwościami reologicznymi z ośrodków o zróżnicowanych parametrach petrofizycznych umożliwia optymalizację projektowanych zabiegów (wybór odpowiedniej metody, redukcja kosztów, wzrost objętości możliwej do eksploatacji ropy naftowej).

Symulacje przepływu płynów realizowane na rzeczywistych próbkach skał zbiornikowych umożliwiają zachowanie oryginalnych parametrów ośrodka porowatego, lecz wykazują 
także pewne ograniczenia. Jednym z podstawowych jest fakt, że materiał rdzeniowy, ze względu na wysokie koszty związane $\mathrm{z}$ jego uzyskaniem, jest bardzo cenny, dlatego też prowadzenie tego typu badań na większą skalę staje się niemożliwe. Alternatywą okazują się sztuczne modele ośrodków po- rowatych zbudowanych z piasku czy kulek szklanych o znanej granulacji. Realizowane przez wielu badaczy [11 $\div 13]$ projekty wskazują na zadowalające wyniki wykorzystania tego typu ośrodków, co otwiera nowy, perspektywiczny obszar dla badań przepływu układów wielofazowych.

\section{Metody eksploatacji złóż ropy naftowej - nawadnianie}

Produkcja ropy naftowej w początkowym etapie eksploatacji złoża odbywa się głównie za pomocą tzw. metod pierwotnych (rysunek 1), wykorzystujących wewnętrzną energię złoża, co pozwala uzyskać niewielki stopień sczerpania pierwotnych zasobów geologicznych, kształtujący się na poziomie $15 \div 20 \%[9,10,15]$. Wraz ze spadkiem energii złożowej następuje zmniejszenie ilości węglowodorów dopływających do otworu wydobywczego. Sytuacja ta wymaga zastosowania tzw. metod wtórnych, czyli dostarczenia do złoża zewnętrznych źródeł energii, którymi mogą być ponownie wtłaczana solanka złożowa lub gaz uzyskany w procesie eksploatacji bądź zatłaczanie wody, jako proces nawadniania złoża. W momencie gdy prowadzenie wydobycia metodami wtórnymi staje się nieefektywne, stosowane są tzw. metody trzecie. Polegają one na dostarczeniu do złoża energii poprzez wprowadzenie do niego mediów niewystępujących w nim w sposób naturalny, które uzupełniają lub zastępują naturalne albo fizyczne mechanizmy wypierania wykorzystywane w metodach pierwotnych i wtórnych $[8,14,15]$. Metody trzecie często określane są jako metody EOR - enhanced oil recovery.

Ważnym czynnikiem determinującym możliwość zastosowania danej metody wspomagania bądź intensyfikacji wy-

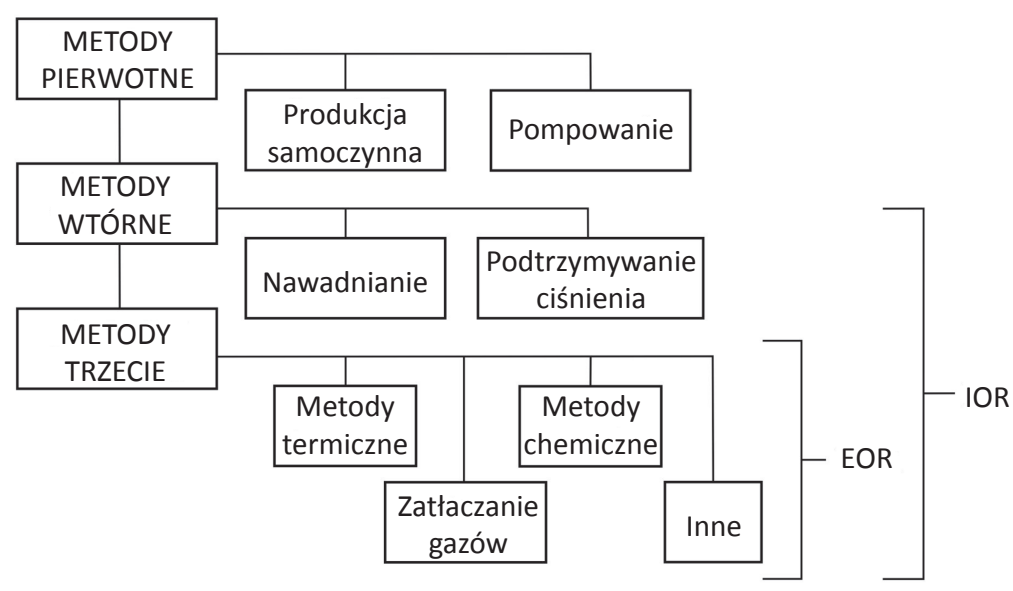

Rys. 1. Metody eksploatacji złóż ropy naftowej [8] dobycia jest aspekt ekonomiczny oraz ograniczenie w postaci minimalnego ciśnienia, poniżej którego niemożliwy staje się samoczynny wypływ płynów złożowych na powierzchnię. Zabiegi nawadniania w porównaniu z pozostałymi metodami są zdecydowanie najtańsze, przy jednocześnie wysokim możliwym do osiągnięcia współczynniku sczerpania. Potwierdza to zasadność wyboru metody nawadniania jako najczęściej stosowanego sposobu podnoszenia/utrzymywania ciśnienia złożowego na poziomie umożliwiającym dopływ ropy naftowej do odwiertu wydobywczego [8].

Nawadnianie złóż ropy naftowej jest jedną z najlepiej rozpoznanych metod zwiększenia współczynnika sczerpania, wykorzystywaną w chwili zakończenia opłacalnej eksploatacji złoża metodami pierwotnymi [10, 11]. Stanowi ona dominujące narzędzie (wśród innych metod zatłaczania mediów do przestrzeni porowej) odpowiadające za zwiększenie poziomu produkcji węglowodorów na większości złóż ropy naftowej [3]. Na przestrzeni lat prowadzone były liczne projekty wspomagania wydobycia metodą nawadniania. Spośród polskich przykładów przytoczyć można między innymi złoża: Osobnica, Kamień Pomorski czy B-3 Petrobaltic [10]. Warunkiem koniecznym prawidłowego zrozumienia zasad planowania oraz przeprowadzenia procesu nawadniania jest wiedza na temat podstawowych właściwości zbiornikowych analizowanego złoża. Zawierają się w tym dwie grupy danych, które związane są z parametrami petrofizycznymi samego ośrodka porowatego, tj. porowatością i przepuszczalnością, oraz z właściwościami układu skała-płyny złożowe: ciśnieniem kapilarnym oraz przepuszczalnością względną [3]. Wielkość współczynnika sczerpania uzyskana w wyniku przeprowadzanych zabiegów nawadniania jest funkcją zwilżalności matrycy skalnej, geometrii wykształcenia przestrzeni porowej i rozkładu jej nasycenia płynami złożowymi [2].

\section{Budowa modeli warstw/złóż z kulek szklanych}

W celu umożliwienia symulacji oraz wizualizacji procesu przepływu ropy naftowej i solanki złożowej w większej skali niż próbki typu plug (rdzeń o średnicy 2,54 cm, długości $4 \div 8 \mathrm{~cm}$ ) wykonane zostały modele warstw/złóż z kulek szklanych o znanej granulacji. Kulki szklane, jako główny element symulowanych warstw/złóż, umieszczane 
były w przeźroczystej obudowie (rys. 2 , nr 3) wykonanej z polimetakrylanu metylu (PMMA) - rura o wymiarach: $35 \mathrm{~cm}$ długości, 2,5 cm średnicy wewnętrznej. W celu zapewnienia szczelności obydwa końce rury zamknięte zostały korkami aluminiowymi (rys. 2, nr 5), zaopatrzonymi w uszczelkę typu o-ring - samoczynnie i dwustronnie działający element uszczelniający. Media użyte do przeprowadzania doświadczenia doprowadzane były do wnę-

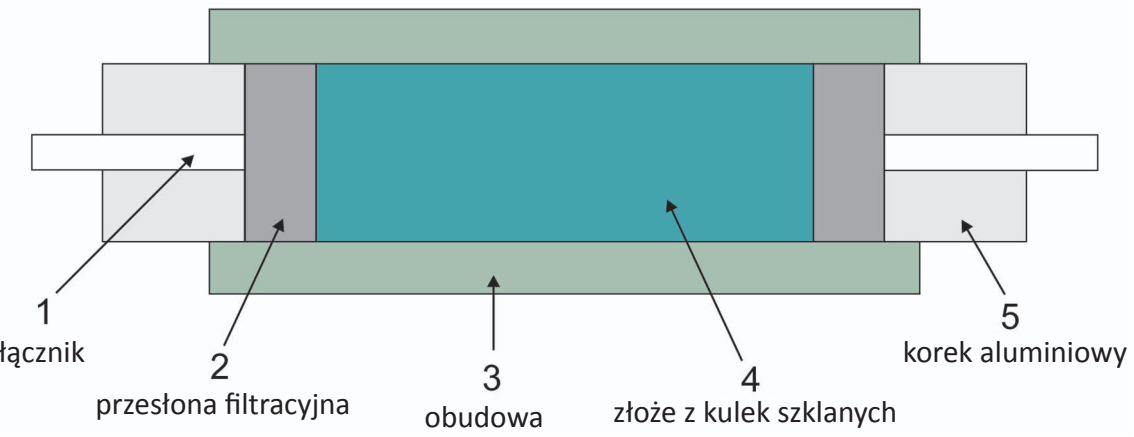

Rys. 2. Schemat budowy homogenicznej „sztucznej” warstwy złożowej trza rury poprzez łączniki (rys. 2, nr 1), umieszczone w centralnej części korków uszczelniających. Aby uniknąć rozmycia zbudowanego modelu i wynoszenia kulek szklanych wraz z przepływającymi mediami przez ujście w korku uszczelniającym (średnica kulek jest kilkukrotnie mniejsza od średnicy rurek odprowadzających), zdecydowano się zastosować przesłonę filtracyjną (rys. 2, nr 2) złożoną z kulek o większej granulacji $(300 \div 400 \mu \mathrm{m})$. Przesłony te umieszczano po obu stronach złoża. Tak przygotowany model warstwy/złoża poddawano pomiarowi przepuszczalności absolutnej dla gazu (azot techniczny). Celem pomiaru było potwierdzenie prawidłowej budowy złoża poprzez stwierdzenie braku widocznych ubytków materiału w wewnętrznej przestrzeni rury oraz wstępna charakterystyka i porównanie właściwości filtracyjnych przygotowanych modeli.

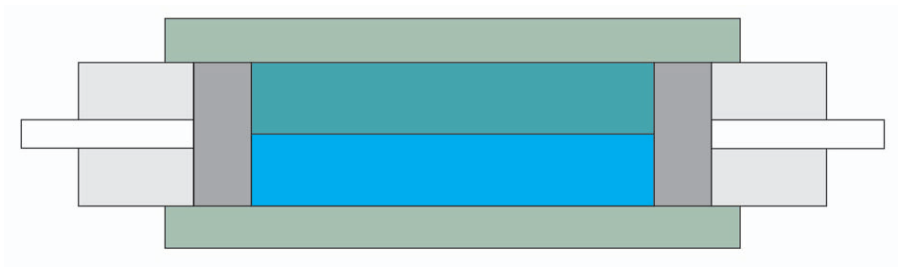

Rys. 3. Schemat budowy złoża heterogenicznego o równoległym układzie warstw

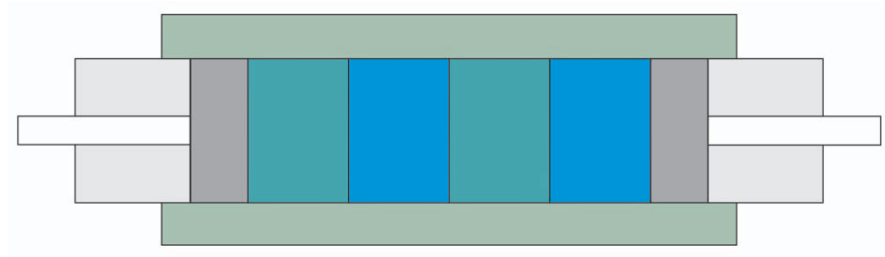

Rys. 4. Schemat budowy złoża heterogenicznego o naprzemiennym układzie warstw

\section{Badania laboratoryjne}

Wykonane warstwy/modele z kulek szklanych o znanej granulacji poddano zestawowi badań mających na celu scharakteryzowanie ich podstawowych parametrów petrofizycznych i filtracyjnych: objętości porowej $(P V)$, porowatości, przepuszczalności absolutnej dla gazu, solanki złożowej oraz przepuszczalności efektywnej dla ropy naftowej (typ A i B). Określony został poziom nasycenia rezydualnego ropą naftową przed i po zabiegu nawadniania - wyznaczono wartość współczynnika sczerpania $R F$ (1) [4]. Dla każdego z modeli wyliczona została liczba kapilarna $N c(2)[1,5,7]$. Aby zobrazować przepływ płynów złożowych przez „,sztuczny” ośrodek porowaty, przeprowadzono symulację procesu nawadniania na dwóch modelach złóż: I - modelu warstw równoległych o zróżnicowanych parametrach filtracyjnych, II - analogicznym modelu warstw równoległych z dodatkową modyfikacją (zmniejszeniem) przepuszczalności dla określonego fragmentu warstwy spągowej. Na podstawie otrzymanych wyników podjęto próbę oceny możliwości zastosowania sztucznych warstw/złóż z kulek szklanych do symulacji przepływu płynów przez ośrodek porowaty.

$$
R F=\left(V_{\text {OLL }} \times 100\right) / O O I P
$$

gdzie:

$V_{O I L}$ - objętość ropy naftowej wypartej przez wodę złożową w trakcie zabiegu nawadniania,

OOIP - objętość ropy naftowej w przestrzeni porowej warstwy/złoża przed zabiegiem nawadniania.

$$
N_{C}=\frac{\vartheta \mu}{\sigma}
$$

gdzie:

$N_{c}$ - liczba kapilarna,

$\vartheta$ - prędkość przepływu Darcy’ego,

$\mu$ - lepkość fazy wypierającej,

$\sigma$ - napięcie międzyfazowe pomiędzy fazami wypełniającymi przestrzeń porową.

Niepewność uzyskanych wyników pomiarów oznaczono na podstawie klasy dokładności urządzeń pomiarowych na poziomie: lepkość $-0,01 \%$, napięcie międzyfazowe $-0,1 \%$, przepuszczalność (absolutna, efektywna) - 3,5\%, objętość porowa $-0,01 \%$, porowatość $-0,01 \%$, współczynnik sczerpania $-0,1 \%$, liczba kapilarna $-0,1 \%$. 


\section{Wyniki badań}

\section{Plyny złożowe}

Użyte do przeprowadzenia badań płyny złożowe scharakteryzowano pod względem ich lepkości dynamicznej oraz napięć międzyfazowych w układzie ropa naftowa-solanka złożowa (tablica 1).

Tablica 1. Wartości lepkości dynamicznych oraz napięć międzyfazowych użytych w badaniach płynów złożowych

\begin{tabular}{|l|c|c|}
\cline { 2 - 3 } \multicolumn{1}{c|}{} & Temperatura pomiaru $\left[{ }^{\circ} \mathrm{C}\right]$ & Lepkość $\mu[\mathrm{cP}]$ \\
\hline Ropa naftowa typu A & 25 & 4,500 \\
\hline Ropa naftowa typu B & 25 & 13,000 \\
\hline Solanka złożowa & 25 & 0,978 \\
\hline & Temperatura pomiaru $\left[{ }^{\circ} \mathrm{C}\right]$ & $\begin{array}{c}\text { Napięcie międzyfazowe } \sigma \\
{[\mathrm{mN} / \mathrm{m}]}\end{array}$ \\
\hline $\begin{array}{l}\text { Ropa naftowa typu A- } \\
\text { solanka złożowa }\end{array}$ & 25 & 4,7 \\
\hline $\begin{array}{l}\text { Ropa naftowa typu B }- \\
\text { solanka złożowa }\end{array}$ & 25 & 7,3 \\
\hline
\end{tabular}

\section{Sztuczne warstwy/ztoża z kulek szklanych}

Na potrzeby realizacji zadania przygotowano zestaw kilku sztucznych warstw/złóż z kulek szklanych o znanej granulacji (tablica 2) - 4 złoża homogeniczne oraz 4 złoża heterogeniczne. Dla złóż heterogenicznych przyjęto dwa warianty układu warstw. Modele $\mathrm{z}$ grupy 3 stanowią układ warstw równoległych (rysunek 3) o frakcji: strop $-0 \div 100 \mu \mathrm{m}$, spąg $-40 \div 80 \mu \mathrm{m}$, w zestawie 4 złoża podzielone zostały na cztery następujące po sobie części (rysunek 4), kolejno: I $(0 \div 100 \mu \mathrm{m})$, II $(40 \div 80 \mu \mathrm{m})$, III $(0 \div 100 \mu \mathrm{m})$, IV $(40 \div 80 \mu \mathrm{m})$.

Analiza podstawowych własności petrofizycznych (tablica 2) wskazuje na prawidłowy i powtarzalny sposób przy- gotowania modeli warstw/złóż homogenicznych. Dla każdej z par otrzymane wartości przepuszczalności, porowatości i objętości porowej pokrywają się ze sobą. W przypadku złóż heterogenicznych (głównie modele 3A i 3B) rozbieżności w uzyskanych wynikach są nieco większe. Spowodowane jest to ograniczeniami technicznymi uniemożliwiającymi precyzyjne zagęszczenie kulek szklanych w trakcie budowy złoża. Niemniej jednak przedstawione modele należy uznać za porównywalne, a występujące różnice za niemające bezpośredniego wpływu na wyniki dalszych badań.

Analiza wyników przedstawionych w tablicy 3 obrazuje wpływ cech petrofizycznych ośrodka porowatego oraz właściwości reologicznych płynów złożowych na wielkość możliwego do uzyskania współczynnika sczerpania $R F$. Każda z par modeli warstw/ złóż homogenicznych (1A, 1B oraz 2A, 2B zbliżone parametry petrofizyczne, różniący się lepkością wypierany płyn złożowy) charakteryzuje się spadkiem współczynnika sczerpania dla układu z ropą naftową o wyższej lepkości. Wartości wyliczonej liczby kapilarnej $N_{c}$ (wydatek zatłaczanej fazy wypierającej równy $1 \mathrm{~cm}^{3} / \mathrm{min}$ ) maleją również z zachowaniem powyższej zależności. Zmiana kryteriów porównywania ośrodków porowatych, tj. stałe parametry reologiczne płynów złożowych, różne właściwości filtracyjne, prowadzi do następujących wniosków: spadek wartości współczynnika $R F$ odbywa się zgodnie ze wzrostem zdolności (przepuszczalności) transportu płynu przez przestrzeń porową ośrodków, co przekłada się na wzrost wartości liczby kapilarnej.

Tablica 2. Zestawienie podstawowych parametrów petrofizycznych sztucznych złóż z kulek szklanych

\begin{tabular}{|c|c|c|c|c|c|}
\hline Lp. & $\begin{array}{l}\text { Frakcja kulek szklanych } \\
\qquad[\mu \mathrm{m}]\end{array}$ & $\begin{array}{l}\text { Długość próbki } \\
{[\mathrm{cm}]}\end{array}$ & $\begin{array}{l}\text { Przepuszczalność absolutna dla gazu } \\
\qquad[\mathrm{mD}]\end{array}$ & $\begin{array}{c}\text { Objętość porowa } \\
{\left[\mathrm{cm}^{3}\right]}\end{array}$ & $\begin{array}{c}\text { Porowatość } \\
{[\%]}\end{array}$ \\
\hline \multicolumn{6}{|c|}{ Warstwy/złoża homogeniczne } \\
\hline $1 \mathrm{~A}$ & $0 \div 100$ & 31,5 & 278,12 & 79,44 & 51,37 \\
\hline $1 \mathrm{~B}$ & $0 \div 100$ & 31,5 & 268,81 & 76,79 & 49,66 \\
\hline $2 \mathrm{~A}$ & $40 \div 80$ & 31,5 & 2176,18 & 60,89 & 39,38 \\
\hline 2B & $40 \div 80$ & 31,0 & 2208,42 & 63,15 & 41,50 \\
\hline \multicolumn{6}{|c|}{ Złoża heterogeniczne - warstwy równoległe } \\
\hline $3 \mathrm{~A}$ & & 32,0 & 1144,55 & 61,49 & 39,15 \\
\hline $3 \mathrm{~B}$ & & 31,5 & 1482,45 & 70,47 & 45,58 \\
\hline \multicolumn{6}{|c|}{ Złoża heterogeniczne - warstwy następujące po sobie } \\
\hline $4 \mathrm{~A}$ & & 31,0 & 451,92 & 66,19 & 43,50 \\
\hline $4 B$ & & 31,5 & 424,54 & 64,60 & 41,78 \\
\hline
\end{tabular}


Tablica 3. Zestawienie wyników pomiarów sztucznych złóż z kulek szklanych

\begin{tabular}{|c|c|c|c|c|c|c|c|c|}
\hline & \multirow{2}{*}{\multicolumn{2}{|c|}{ Nawadnianie solanką złożową }} & \multirow{3}{*}{$\begin{array}{c} \\
\text { Liczba } \\
\text { kapilarna } \\
N c\end{array}$} \\
\hline & & & & & & & & \\
\hline Lp. & $\begin{array}{l}\text { Typ ropy } \\
\text { naftowej }\end{array}$ & $\begin{array}{c}\text { Objętość } \\
\text { porowa } \\
{\left[\mathrm{cm}^{3}\right]}\end{array}$ & $\begin{array}{l}\text { Przepuszczalność } \\
\text { absolutna dla } \\
\text { solanki złożowej } \\
{[\mathrm{mD}]}\end{array}$ & $\begin{array}{c}\text { Przepuszczalność } \\
\text { efektywna dla } \\
\text { ropy } \\
{[\mathrm{mD}]}\end{array}$ & $\begin{array}{c}\text { Nasycenie } \\
\text { ropą naftową } \\
\text { przed zabie- } \\
\text { giem nawad- } \\
\text { niania OOIP } \\
{\left[\mathrm{cm}^{3}\right]}\end{array}$ & $\begin{array}{c}\text { Objętość ropy } \\
\text { naftowej wy- } \\
\text { partej w trak- } \\
\text { cie zabiegu na- } \\
\text { wadniania } V_{\text {OIL }} \\
{\left[\mathrm{cm}^{3}\right]}\end{array}$ & $\begin{array}{c}\text { Współczynnik } \\
\text { sczerpania } R F \\
{[\%]}\end{array}$ & \\
\hline \multicolumn{9}{|c|}{ Warstwy/złoża homogeniczne } \\
\hline $1 \mathrm{~A}$ & A & 79,44 & 187,55 & 70,57 & 59,0 & 39,0 & 66,1 & $1,3 \times 10^{-5}$ \\
\hline $1 \mathrm{~B}$ & B & 76,79 & 175,71 & 55,74 & 61,0 & 36,0 & 59,0 & $0,9 \times 10^{-5}$ \\
\hline $2 \mathrm{~A}$ & A & 60,89 & 1375,37 & 377,48 & 52,0 & 29,0 & $\mathbf{5 5 , 8}$ & $1,9 \times 10^{-5}$ \\
\hline $2 \mathrm{~B}$ & $\mathrm{~B}$ & 63,15 & 1292,01 & 623,84 & 56,0 & 25,0 & 44,6 & $1,1 \times 10^{-5}$ \\
\hline \multicolumn{9}{|c|}{ Złoża heterogeniczne - warstwy równoległe } \\
\hline $3 \mathrm{~A}$ & A & 61,49 & 872,02 & 511,38 & 47,0 & 36,0 & 76,6 & $1,8 \times 10^{-5}$ \\
\hline $3 \mathrm{~B}$ & $\mathrm{~B}$ & 70,47 & 831,57 & 565,07 & 55,0 & 30,0 & 54,5 & $1,0 \times 10^{-5}$ \\
\hline \multicolumn{9}{|c|}{ Złoża heterogeniczne - warstwy następujące po sobie } \\
\hline $4 \mathrm{~A}$ & A & 66,19 & 289,85 & 171,15 & 53,0 & 34,0 & 64,1 & $1,6 \times 10^{-5}$ \\
\hline $4 \mathrm{~B}$ & B & 64,60 & 247,98 & 277,78 & 54,0 & 31,0 & 57,4 & $1,1 \times 10^{-5}$ \\
\hline
\end{tabular}

Rezultaty zestawione dla złóż heterogenicznych obrazują dwa różniące się układem warstw modele. Zarówno zestaw 3(A/B) - warstwy równoległe (rysunek 3), jak i 4(A/B) - war- stwy następujące po sobie (rysunek 4) - charakteryzują się spadkiem współczynnika sczerpania oraz wartości liczby kapilarnej wraz ze wzrostem lepkości ropy naftowej.

\section{Symulacja procesu nawadniania sztucznego złoża z kulek szklanych}

W wyniku przeprowadzenia procesu nawadniania sztucznego złoża z kulek szklanych, zbudowanego z dwóch równoległych warstw o zróżnicowanych parametrach filtracyjnych (fotografia 1), otrzymany współczynnik sczerpania $R F$ odpowiada objętości ropy naftowej wypartej głównie z warstwy spągowej analizowanego modelu. Na fotografii 1A przedstawiono początkowy etap zatłaczania solanki złożowej. Dolna warstwa ma ciemniejszą barwę, co sugeruje większe nasycenie ropą naftową. Fotografia 1B obrazuje etap, gdy front fazy wypierającej znajduje się w połowie długości złoża. Obszar warstwy spągowej zajęty przez solankę jest znacznie jaśniejszy - część ropy została wyparta w wyniku zabiegu nawadniania. Na fotografii $1 \mathrm{C}$ widoczny jest finalny etap symulowanego procesu - doszło do przebicia i wypływu solanki po pra- wej/końcowej stronie złoża. W trakcie zabiegu nie zaobserwowano widocznej zmiany w barwie warstwy stropowej, co może wskazywać na brak lub nieznaczną objętość wypartej z niej ropy. Opisane zmiany spowodowane są znacznie wyż-

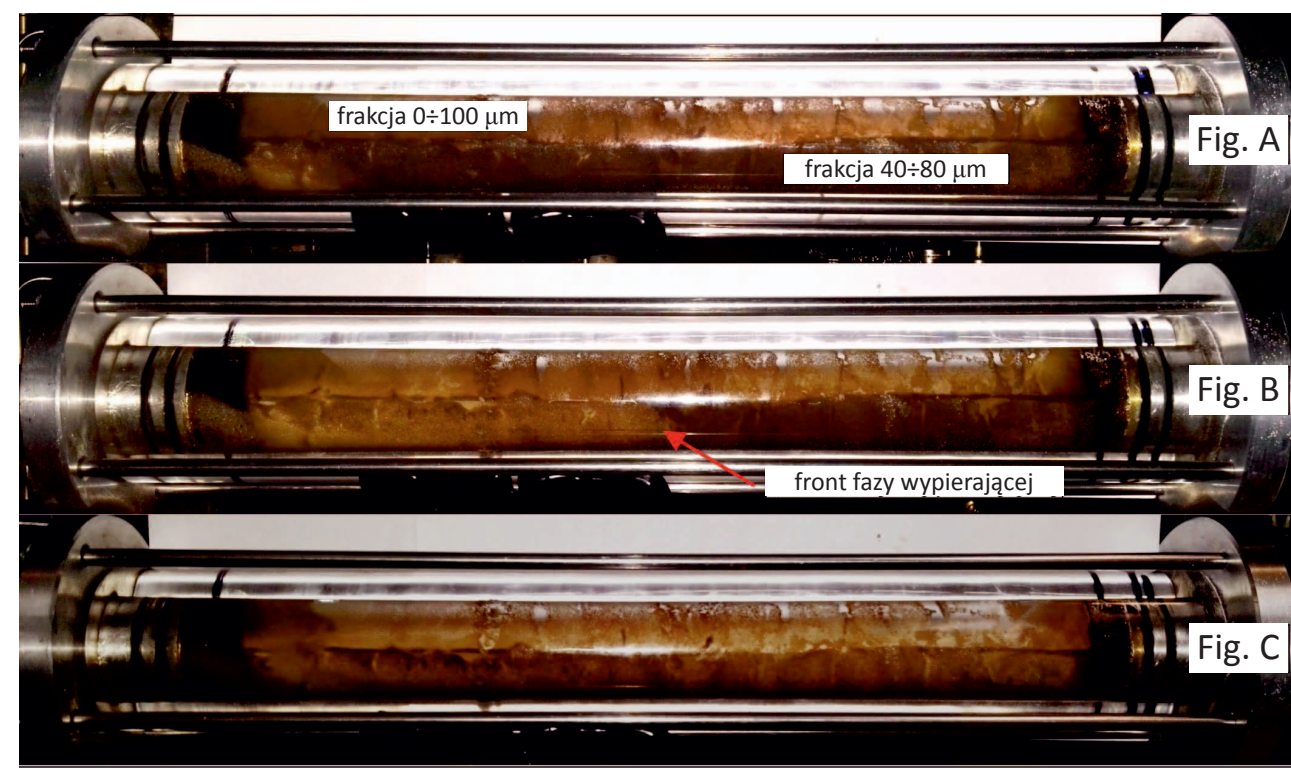

Fot. 1. Wizualizacja symulacji zabiegu nawadniania heterogenicznego złoża zbudowanego $\mathrm{z}$ dwóch warstw równoległych (warstwa stropowa - frakcja $0 \div 100 \mu \mathrm{m}$, warstwa spągowa - frakcja $40 \div 80 \mu \mathrm{m})$ 
szą przepuszczalnością (potwierdzoną wcześniejszymi pomiarami, tablice 2 i 3) warstwy spągowej i budującej ją frakcji $40 \div 80 \mu \mathrm{m}$ w stosunku do warstwy stropowej. Interpretacja zmian barw wskazuje na kierunek przepływu większości objętości fazy wypierającej (solanki złożowej) w trakcie symulowanego procesu. Wynika z tego, że znaczna ilość ropy naftowej pozostaje nadal w przestrzeni porowej mniej przepuszczalnej warstwy stropowej (frakcja $0 \div 100 \mu \mathrm{m})$ i nie jest możliwe jej wyparcie w wyniku kontynuowania zabiegu.

Celem wprowadzania wtórnych oraz trzecich metod eksploatacji jest podnoszenie wartości współczynnika sczerpania węglowodorów. Przedstawiony w poprzednim akapicie przypadek nawadniania złoża zbudowanego z dwóch warstw o różnych parametrach filtracyjnych wskazuje jednoznacznie na potrzebę zwiększania efektywności takich zabiegów. Aby podnieść współczynnik sczerpania ropy naftowej dla stropowej warstwy o niższej przepuszczalności, podjęto próbę obniżenia parametrów filtracyjnych warstwy spągowej poprzez wstawienie do niej na określonym odcinku (fotografia 2A, sekcja II) frakcji $0 \div 100 \mu \mathrm{m}$. Zasymulowany zabieg modyfikacji przepuszczalności miał na celu odcięcie/zmniejszenie przepływu solanki złożowej przez wskazany odcinek złoża. Tego typu działania (RPM - relative permeability modification) w skali

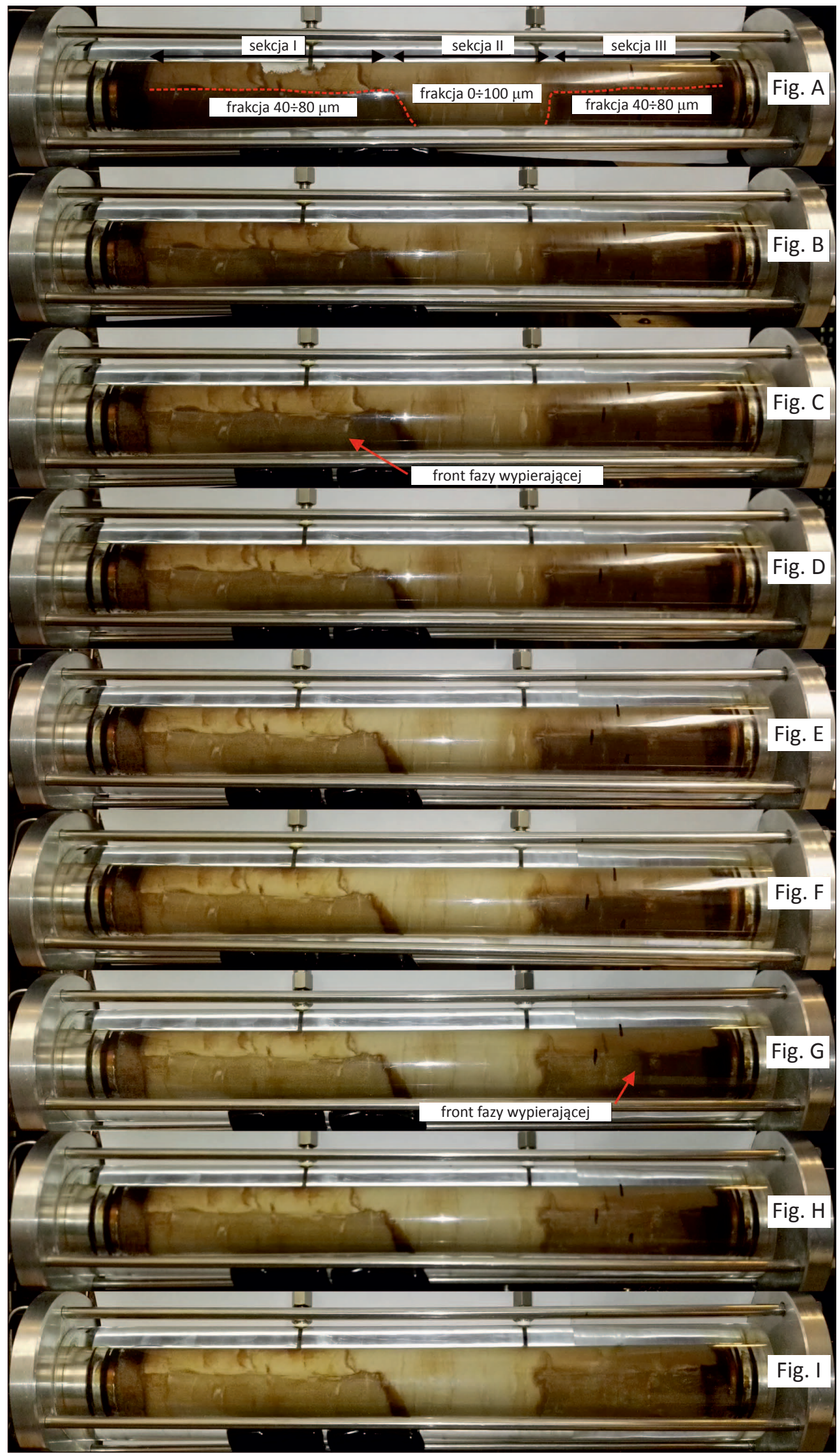

Fot. 2. Wizualizacja symulacji zabiegu nawadniania heterogenicznego złoża zbudowanego z dwóch warstw równoległych, z częściową redukcją przepuszczalności warstwy spągowej w sekcji II (warstwa stropowa - frakcja $0 \div 100 \mu \mathrm{m}$, warstwa spągowa - frakcja $40 \div 80 \mu \mathrm{m}$ ) 
odwiertu sprowadzają się do zatłoczenia cieczy zabiegowej na określoną głębokość w przestrzeń porową strefy przyodwiertowej, której interakcje ze skałą zbiornikową prowadzą do zmniejszenia właściwości filtracyjnych ośrodka porowatego dla wody złożowej [6]. Dla tak zbudowanego złoża spodziewano się osiągnąć wyższy poziom nasycenia fazą wypierającą centralnego odcinka warstwy stropowej. Wizualizacja przebiegu procesu na fotografiach 2B i C pokrywa się z jego przebiegiem z poprzedniego modelu. Następnie front fazy wypierającej po dotarciu do odcinka warstwy spągowej o zredukowanej przepuszczalności (fotografia 2D) zmienia kierunek swojej propagacji, następuje stopniowa ekspansja solanki do przestrzeni porowej warstwy stropowej. W sekcji II, w warstwach zbudowanych z tej samej frakcji kulek szklanych, front przemieszcza się całą średnicą złoża, tempo jego przemieszczania spada, następuje wzrost ciśnienia zatłaczania solanki złożowej. Kontynuacja przepływu fazy wypierającej (fotografia 2E) skutkuje zmianą barwy odcinka warstwy stropowej (sekcja I) - przypuszczalny wzrost objętości wypartej ropy naftowej. Moment osiągnięcia przez front wypierający odcinka o ponownym rozdziale właściwości filtracyjnych - sekcja III (fotografia 2 F) objawia się szybkim spadkiem ciśnienia tłoczenia oraz ,powrotem” przepływu frontu wypierającego przez warstwę spągową (fotografia $2 \mathrm{G}$ ). Fotografie $2 \mathrm{H}$ i 2I obrazują kontynuację tego przepływu aż do momentu przebicia się fazy wypierającej i jej wypływu po prawej/końcowej stronie złoża.

Ocena barwy poszczególnych odcinków modelu może wskazywać na wzrost współczynnika sczerpania warstwy stropowej w sekcji o zmniejszonej przepuszczalności warstwy spągowej. Na podstawie wizualizacji symulacji obu procesów nawadniania nie jest możliwe ich bezpośrednie porównanie pod względem efektywności przeprowadzanego zabiegu. W celu weryfikacji prawidłowej interpretacji przeprowadzonego doświadczenia wykonano badanie poziomu nasycenia ropą naftową warstw budujących analizowane złoża po procesie nawadniania. Na fotografii 3B przedstawiono układ warstw złoża heterogenicznego zbudowanego z dwóch równoległych warstw po zabiegu nawadniania, a także miejsca poboru próbek budujących je frakcji. Z każdego punktu pobrano 1 gram materiału w celu określenia objętości ropy naftowej pozostałej w przestrzeni porowej danej warstwy po przeprowadzeniu procesu nawadniania. Próbki umieszczono w próbówkach, a następnie zalano wodą destylowaną o temperaturze $45^{\circ} \mathrm{C}$ (fotografia $3 \mathrm{~A}$ ). W wyniku ekstrakcji materiału otrzymano informację na temat objętości ropy naftowej zawartej w pobranych objętościach kulek szklanych budujących obydwie warstwy złoża. Na podstawie interpretacji uzyskanych wyników należy stwierdzić, że:

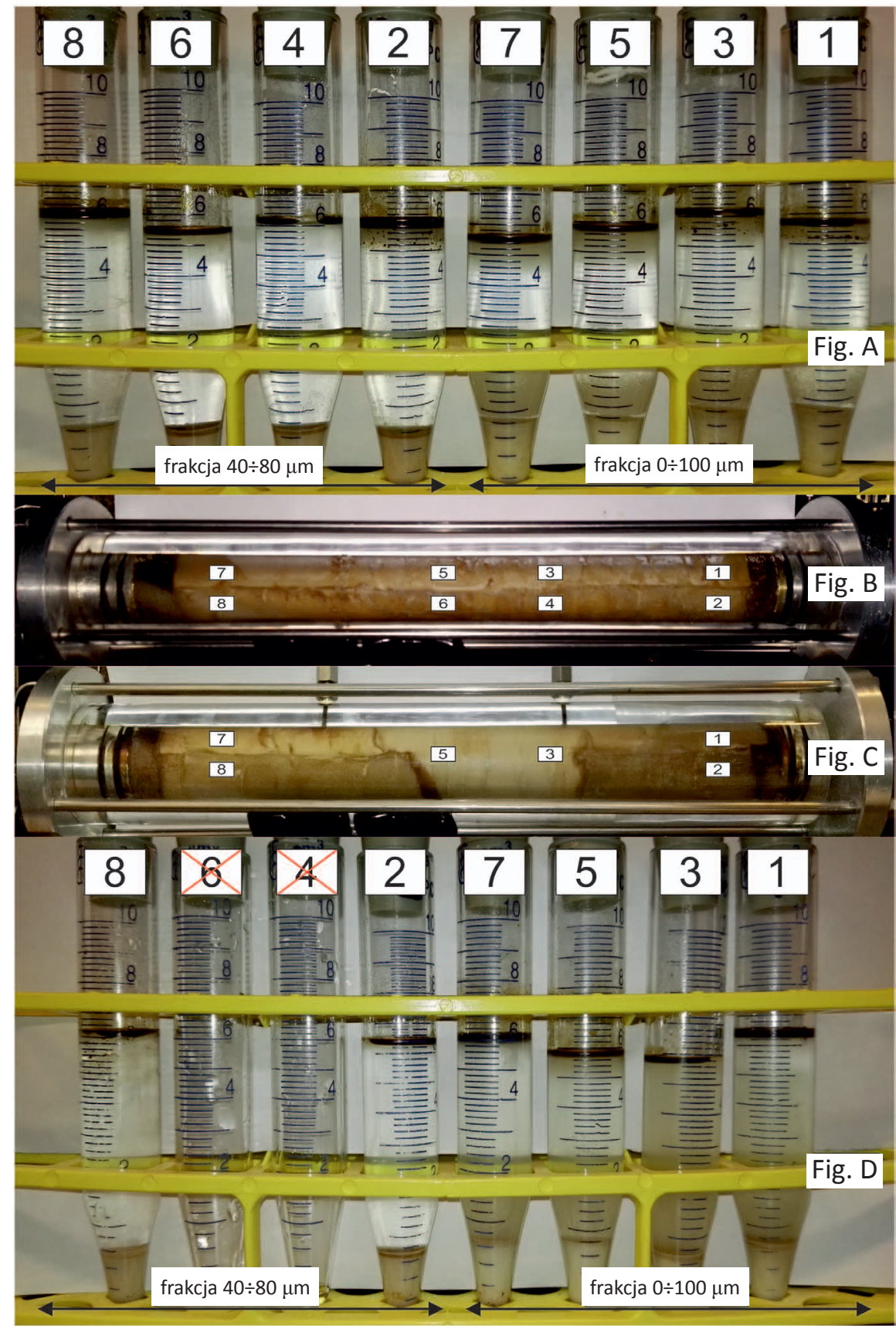

Fot. 3. Poziom nasycenia ropą naftową po symulacji zabiegu nawadniania heterogenicznego złoża zbudowanego $\mathrm{z}$ dwóch warstw równoległych $(\mathrm{A}, \mathrm{B})$ oraz heterogenicznego złoża zbudowanego $\mathrm{z}$ dwóch warstw równoległych $\mathrm{z}$ częściową redukcją przepuszczalności warstwy spągowej $(\mathrm{C}, \mathrm{D})$ 
- w przypadku warstwy spągowej (frakcja $40 \div 80 \mu \mathrm{m}$ ) objętości ropy naftowej pozostałej w przestrzeni porowej po zabiegu nawadniania są równe dla punktów 6 i 4. Zwiększone objętości uzyskane dla punktów skrajnych $(2,8)$ mogą wynikać z oddziaływania na przepływające przez warstwę płyny efektów brzegowych, które mogły wpłynąć na rozkład nasyceń w tych partiach złoża;

- w przypadku warstwy stropowej (frakcja $0 \div 100 \mu \mathrm{m}$ ) otrzymane objętości ropy naftowej są zbliżone dla wszystkich czterech punktów pomiarowych. Wskazuje to na równomierne nasycenie przestrzeni porowej ropą naftową, a jednocześnie na przypuszczalny brak procesu wypierania jej przez solankę złożową w trakcie zabiegu nawadniania.

Dla modelu złoża z wprowadzoną modyfikacją przepuszczalności warstwy spągowej w sekcji II (fotografia 3C) uzyskane objętości ropy naftowej z pobranych prób wskazują na zmiany nasyceń przestrzeni porowej płynami złożowymi w porównaniu do wyżej opisanego układu. Celem redukcji właściwości filtracyjnych warstwy spągowej było uzyskanie wyższego stopnia „odropienia” warstwy stropowej. Analiza otrzymanych wyników (fotografia 3D) wskazuje, że został on osiągnięty:

- Uzyskane wyniki dla warstwy spągowej (próbówki nr 2 i $\mathrm{nr}$ 8) informują o zbliżonym poziomie nasycenia ropą naftową dla krańcowych sekcji analizowanego złoża. Pokrywają się one z rezultatami z poprzedniego modelu.

- Objętości ropy naftowej otrzymane z próbek frakcji $0 \div 100 \mu \mathrm{m}$ różnią się od siebie. Dla prób $\mathrm{nr} 3$ i nr 5 są one mniejsze względem dwóch pozostałych. Wskazuje to na zwiększenie współczynnika sczerpania w tym odcinku złoża. W obrębie sekcji II próbki nr 3 i nr 5 pobrane zostały ze środkowych partii przekroju poprzecznego, jako najbardziej reprezentatywnego obszaru dla pomiaru poziomu nasyceń przestrzeni porowej płynami złożowymi. Widoczne różnice w objętości wypartej ropy naftowej pomiędzy próbkami nr 3 i nr 5 na fotografii 3A i D potwierdzają jednoznacznie skuteczność procesu redukcji przepuszczalności warstwy spągowej, jako głównej strefy przepływu zatłaczanej w czasie zabiegu nawadniania solanki złożowej. Potwierdzono w ten sposób także możliwość przeprowadzania symulacji wskazanych zabiegów na sztucznych złożach z kulek szklanych. Zasadne wydaje się również założenie możliwości symulowania i analizy innych procesów związanych z przepływem płynów przez ośrodki porowate.

\section{Podsumowanie i wnioski}

W wyniku przeprowadzonych pomiarów możliwe było wskazanie głównych zależności determinujących przepływ płynów złożowych przez ośrodek porowaty, wynikających ze zmian jego właściwości petrofizycznych oraz parametrów reologicznych mediów wypełniających przestrzeń porową analizowanego ośrodka.

Głównym celem pracy była ocena możliwości symulacji przepływu płynów złożowych przez sztuczny ośrodek porowaty - warstwy/złoża z kulek szklanych. Dane uzyskane z pomiarów dla złóż homogenicznych i heterogenicznych (tablica 3) potwierdziły predyspozycje tych układów do symulacji procesów mogących zachodzić w przestrzeni porowej złóż węglowodorów, np. zabiegów nawadniania czy modyfikacji przepuszczalności (RPM). Wnioski wysunięte na tej podstawie są następujące:

1. Podstawowe parametry petrofizyczne (tablica 2 ) sztucznych warstw/złóż z kulek szklanych pokrywają się z danymi literaturowymi.

2. Wyliczone liczby kapilarne (tablica 3) wykazują trend spadku ich wartości dla stałych parametrów filtracyjnych wraz ze wzrostem lepkości ropy naftowej. Odwrotne zestawienie analizowanych modeli - stałe właściwości reologiczne płynów złożowych - wskazuje na wzrost wyznaczonego parametru wraz ze wzrostem właściwości filtracyjnych ośrodka porowatego.
3. Przy stałej wartości pierwszego parametru (właściwości filtracyjne lub reologiczne) wzrost drugiego powoduje spadek współczynnika $R F$.

4. Złoża heterogeniczne pod względem wyników pomiarów (tablica 3) analizowane powinny być jako dwa odrębne ośrodki. Dla każdego z nich wyznaczone wartości liczby kapilarnej i współczynnika sczerpania zachowują trend ich spadku wraz ze wzrostem lepkości ropy naftowej.

Drugą częścią pracy była symulacja procesu nawadniania sztucznego złoża heterogenicznego. Miała ona na celu wizualizację przebiegu wypierania ropy naftowej oraz potwierdzenie poprawności zaprojektowanego eksperymentu. Symulację zabiegu przeprowadzono na dwóch modelach złóż:

- modelu warstw równoległych (fotografia 1),

- modelu warstw równoległych z modyfikacją (redukcją) przepuszczalności dla określonego fragmentu warstwy spągowej (fotografia 2).

Interpretacja uzyskanych wyników możliwa była dzięki analizie dokumentacji fotograficznej procesu oraz wykonaniu prostego badania poziomu nasycenia przestrzeni porowej w wybranych punktach modeli (fotografia 3 ). Na podstawie otrzymanych danych sformułowano następujące wnioski:

5. Dla złoża zbudowanego z warstw równoległych (fotografia 1) front fazy wypierającej (solanka złożowa) 
przemieszcza się głównie warstwą spągową (frakcja

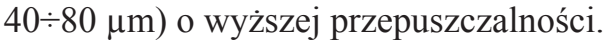

6. Modyfikacja przepuszczalności warstwy spągowej (fotografia 2, sekcja II) umożliwia zwiększenie współczynnika sczerpania dla warstwy stropowej (frakcja $0 \div 100 \mu \mathrm{m}$ ) o niższej przepuszczalności.

7. Porównanie objętości ropy naftowej wyekstrahowanej z jednego grama kulek szklanych (miejsca poboru zaznaczone na fotografii 3), budujących poszczególne warstwy, potwierdza spadek nasycenia rezydualnego ropą naftową w sekcji II warstwy stropowej.

8. Przeprowadzony proces nawadniania wskazuje, że zastosowanie kulek szklanych do budowy modeli sztucznych warstw/złóż jest prostym narzędziem symulacji i anali- zy procesów związanych z przepływem płynów przez ośrodki porowate.

9. Wykonane warstwy/złoża z kulek szklanych pozwoliły opracować metodykę budowy modeli sztucznego ośrodka porowatego. Na tej podstawie możliwe jest projektowanie układów o powtarzalnych parametrach petrofizycznych, co stanowi warunek konieczny i umożliwiający projektowanie np. serii badań określających współczynnik sczerpania dla układów płynów o różnych parametrach reologicznych.

10. Wydaje się, że proponowany sposób symulacji i wizualizacji przepływu płynów przez sztuczne warstwy/złoża z kulek szklanych jest perspektywicznym obszarem badań, mogącym stanowić uzupełnienie wiedzy na temat przepływu układów wielofazowych w ośrodkach porowatych.

Prosimy cytować jako: Nafta-Gaz 2017, nr 6, s. 378-386, DOI: 10.18668/NG.2017.06.02

Artykuł nadesłano do Redakcji 19.12.2016 r. Zatwierdzono do druku 7.04.2017 r.

Artykuł powstał na podstawie pracy statutowej pt. Analiza mechanizmu przepływu płynów przez ośrodek porowaty - praca INiG - PIB na zlecenie MNiSW; nr zlecenia: 21/SI, nr archiwalny: SI-4101-21/16.

\section{Literatura}

[1] Abeysinghe K., Fjelde I., Lohne A.: Dependency of Remaining Oil Saturation on Wettability and Capillary Number. SPE Saudi Arabia Section Technical Symposium and Exhibition, Al-Khobar 2012.

[2] Anderson W.G.: Wettability Literature Survey - Part 6: The Effects of Wettability on Waterflooding. Journal of Petroleum Technology 1987, vol. 39, no. 12, s. 1605-1622.

[3] Craig F.F.: The Reservoir Engineering Aspects of Waterflooding. Society of Petroleum Engineers, 1971.

[4] Dake L.P.: Fundamentals of Reservoir Engineering. Elsevier, 2001.

[5] Ding M., Kantzas A.: Investigation of Critical Capillary Number for Gas-Water System Through Experiment and Reservoir Simulation. Society of Core Analysts, Toronto 2005.

[6] Falkowicz S., Dubiel S., Cicha-Szot R.: Problemy ograniczania doptywu wody do odwiertów wydobywczych gazowych i ropnych. Gospodarka Surowcami Mineralnymi 2012, t. 28, nr 1, s. 125-136.

[7] Guo H., Dou M., Hanqing W., Wang F., Yuanyuan G., Yu Z., Yansheng W., Li Y.: Review of Capillary Number in Chemical Enhanced Recovery. SPE Kuwait Oil \& Gas Show Conference, Kuwejt 2015.

[8] Lake L.W., Johns R.T.: Fundamentals of Enhanced Oil Recovery. Society of Petroleum Engineers, 2014.

[9] Lubaś J.: O potrzebie bardziej dynamicznego wdrażania metod wspomagania wydobycia ropy naftowej z krajowych złóż. Nafta-Gaz 2013, nr 10, s. 744-750.

[10] Lubaś J., Szott W., Dziadkiewicz M.: Analiza możliwości zwiększenia stopnia sczerpania zasobów złóż ropy naftowej $w$ Polsce. Nafta-Gaz 2012, nr 8, s. 481-489.

[11] Mai A., Kantzas A.: Heavy Oil Water Flooding: Effects of Flow Rate and Oil Viscosity. Journal of Canadian Petroleum Technology 2009, vol. 48, no. 3 s. 42-51.

[12] Mai A., Kantzas A.: Improved Heavy Oil Recovery by Low Rate Waterflooding. SPE International Thermal Operations and Heavy Oil Symposium, Calgary 2008.

[13] Metin C.O., Bonnecaze R.T., Nguyen Q.P.: The Viscosity of Silica Nanoparticle Dispersions in Permeable Media. SPE International Oilfield Nanotechnology Conference, Noordwijk 2012.

[14] Rychlicki S., Stopa J., Uliasz-Misiak B., Zawisza L.: Kryteria typowania złóż do zastosowania zaawansowanej metody wydobycia ropy naftowej poprzez zatłaczanie $\mathrm{CO}_{2}$. Gospodarka Surowcami Mineralnymi 2011, t. 27, z. 3, s. 125-139.

[15] Terry R.E.: Enhanced Oil Recovery. Encyclopedia of Physical Science and Technology 3rd Edition 2001, vol. 13, s. 503-509.

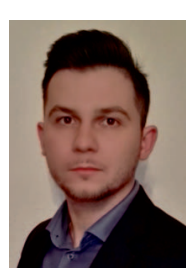

Mgr inż. Marcin MAJKRZAK

Asystent w Zakładzie Inżynierii Naftowej.

Instytut Nafty i Gazu - Państwowy Instytut Badawczy

ul. Lubicz 25 A

31-503 Kraków

E-mail:marcin.majkrzak@inig.pl 